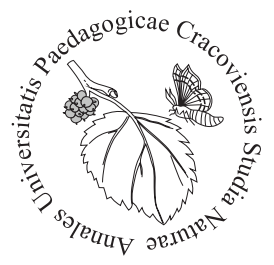

Anna Kocoń1* ${ }^{*}$ Sylwia Janiczek¹, Natalia Malejky-Kłusek²

${ }^{1}$ Department of Zoology, Institute of Biology, Pedagogical University of Krakow, Podchorążych 2 St., 30-084 Kraków, Poland, *a_kocon@wp.pl ${ }^{2}$ Department of Ecology and Environmental Protection, Institute of Biology, Pedagogical University of Krakow, Podchorążych 2 St., 30-084 Kraków, Poland

\title{
Methods of protection against ticks (Acari: Ixodida)
}

Ticks are ruthless, dangerous ectoparasites that attack a large host circle. They are in the second place, after mosquitoes, in the rank of dangerous blood-drinking arthropods. The increased pace of urbanization and weather variability in recent decades have created new, convenient conditions for ticks to be found among people and pets. It is particularly dangerous as ticks carry numerous pathogens and spread tick-borne diseases, such as: Lyme borreliosis, tick-borne encephalitis (Fig. 1A-B), babesiosis, granulocytic anaplasmosis.

Depending on the morphological structure, ticks can be divided into proper (hard) (Ixodidae) and Argasidae (soft ticks) (Argasidae). Of the 19 species of ticks permanently found in the Polish fauna, Ixodes ricinus L. is - the common tick (Siuda, 1991) is the most common of the hard ticks (Appendix 1A). It occurs in green areas - not only along forest paths, in glades, and forest roads, but also increasingly in home gardens, playgrounds, and recreational places. In addition to the fact that ticks can be found in nature, during trips, picnics, walks, we also cannot feel safe in farm buildings and our own homes, due to the possible occurrence of a soft tick, Argas reflexus Fabr., attacking mainly nocturnal rock pigeons in lofts, attics of buildings, on church towers (Appendix 1B).

In terms of location of their occurrence, we can divide ticks into three ecological groups (Siuda, 1991) (Tab. 1): nest-burrow ticks - occurring in lofts, attics, caves, basements, animal cavities and burrows, in the nests of mammals and birds, and in their hollows on trees or in rock shelters. These ticks are usually host-specific species, they spend their entire lives in hideouts, where they can feed on their host who lives, sleeps, breeds and hibernates there. In hidden habitats, there are small fluctuations in climatic conditions; non-nest ticks - found in litter, near bird nests built on trees, among vegetation. They occupy more open environments, feed on busy, migrating 
hosts, and are not attached to strictly located whereabouts and breeding of hosts. The survival of a hungry tick in such conditions depends mainly on its tolerance to changing environmental conditions, such as temperature, light, humidity; non-nest-burrow ticks - larvae and nymphs occur at the entrance and inside the burrows of mammals, while adults are non-nest parasites.

The differences in protection against tick attacks are primarily related to our whereabouts, and thus the possibility of encountering this dangerous parasite on its way. There are several options for protection against tick attacks, but there is no $100 \%$ effective way to avoid these parasites.
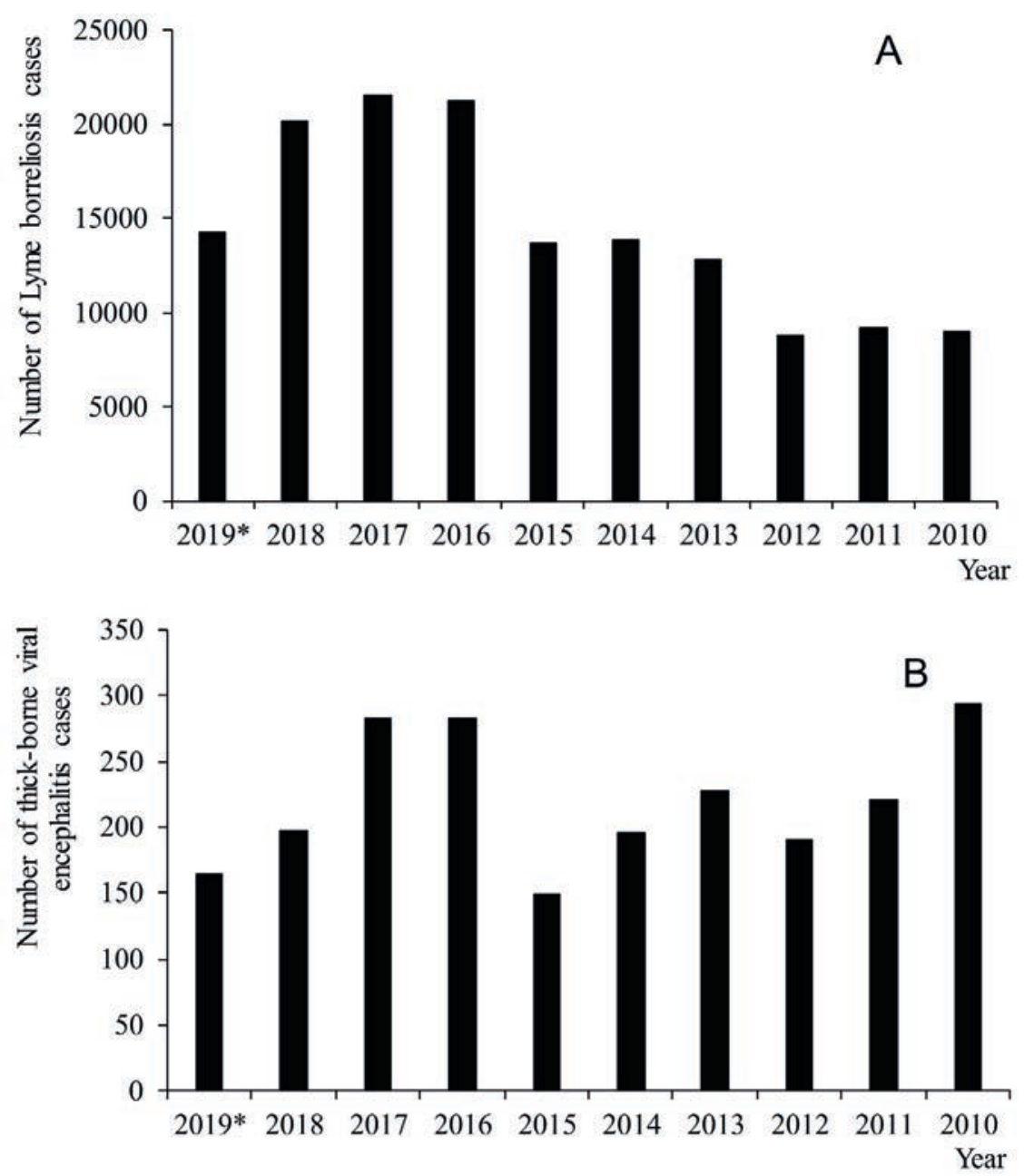

Fig. 1. The number of cases of selected tick-borne diseases in Poland; A - Lyme borreliosis, B - Tickborne viral encephalitis;

*Data for day 30.09.2019 (Source: http://wwwold.pzh.gov.pl/oldpage/epimeld/index_p.html) 
Tab. 1. Ecological groups of ticks found in Poland

\begin{tabular}{ll}
\hline Ecological group & \\
\hline & Argas polonicus Siuda, Hoogstraal, Clifford et Wassef \\
& A. reflexus Fabricius \\
& Carios vespertilionis Latreille \\
& Ixodes apronophorus Latreille \\
& I. arboricola Schulze \& Schlottke \\
I. caledonicus Nuttall \\
I. crenulatus Koch \\
I. hexagonus Leach \\
I. lividus Koch \\
I. rugicollis Schulze \& Schlottke \\
I. simplex Neumann \\
I. vespertilionis Koch \\
Haemaphysalis concinna Koch \\
H. punctata Canestrini \& Fanzago \\
Ixodes frontalis Panzer \\
I. persulcatus Schulze \\
I. ricinus Linneus \\
I. trianguliceps Birula \\
Dermacentor reticulatus Fabricius - adults form \\
Don-nest
\end{tabular}

Ticks on the host's body are looking for a suitable place, most often they are parts of the body with delicate skin, sweating: under the knees, groin, navel, armpits, at the base of the hair/neck, shoulders or behind the ears. In the case of pets, foraging of ticks is most often found around the neck, head, less often on the back and around the tail/ anus (Siuda, 1991).

To defend against tick attacks, the following simple guidelines should be observed: avoid places typical for ticks (forest edges, forest paths, mid-forest clearings, animal trails covered with tall grass and bushes), thus avoid resting on the grass or in places covered with tall grass, lush vegetation, bushes; put on appropriate clothing, suitable for going out into the field, which will prevent ticks from moving onto the naked body: long trousers, with socks rolled out, high shoes, a long-sleeved sweatshirt inserted into trousers, headgear, neck coverage; use tick repellents in the form of sprays, creams, impregnation of things that are exposed to tick attacks, e.g. clothing, tents, blankets, footwear; parasite repellents should also be used for pets/farm animals; check the body for any ticks on clothing or exposed areas of the body; the tick inserted into the body should be removed as soon as possible using hygienic tweezers or special pliers available at pharmacies, pet stores; after returning home, check the body and the removed clothing, because ticks can wander unnoticed on the body or clothing; if we take a dog or a cat out, we also check its whole body after returning home; in addition, 
taking a shower and thorough cleaning with a sponge can help get rid of ticks; people who often spend time actively in the nature, on trips or actively working professionally with the forest and green areas should receive protective vaccinations against tickborne encephalitis after consulting a doctor.

The most commonly used procedures in the human environment aimed at reducing the number of ticks are: draining of wetlands, cutting or moving vegetation; systematic mowing of grass, removal of bushy thickets; limiting access of rodents and other wild animals to human buildings: removal of hideouts, landfills; in the case of soft ticks, systematic disinfection and protection of animal husbandry places: observation of farm animals, in lofts, checking the technical condition of the rooms; not allowing farm animals to move to human housing; rotations of pastures for grazing animals.

In recent years, attempts have been made to use natural organisms to fight ticks. These experiments are currently carried out on selected tick species, they are not longterm studies, so there is no $100 \%$ certainty that the given examples of animals eliminating tick populations can be used on a larger scale.

Among the animals, we can mention several examples that can reduce the population of ticks in the environment - ants: fire ant (Solenopsis invicta Bur.) (Castellanos et al., 2016); beetles: Staphylinus caesareus Ceder. - currently rare due to the use of a large number of spraying (Samish, Alekseev, 2001); bed bugs; butterfly larvae; flies: Ixodiphagus hookeri How., a small insect laying eggs in a tick larvae, which then becomes food for the hatched wasp larvae (Collatz et al., 2010) (Appendix 1 C-D); reptiles: sand lizard (Lacerta agilis L.); birds: domestic hens (Gallus gallus domesticus L.), ducks (Anas sp.), turkeys (Meleagris gallopavo L.), black grouse (Lyrurus tetrix L.), pheasants (Phasianus colchicus L.), partridges (Perdix perdix L.), helmeted guineafowl (Numida meleagris L.) - the fact that guineafowl eat adult ticks was confirmed by scientific research in 1990 in the USA (Duffy et al., 1992), red-billed oxpecker (Buphagus erythrorhynchus Stan.) (Bezuidenhout, Stutterheim, 1980), cattle egret (Bubulcus ibis L.); rodents: sorex, mice - deer mice (Peromyscus leucopus Rafin.) (Shaw et al., 2003), rats (Rattus sp. G. Fischer). Researchers (Angelo et al., 2015) inform that also some viruses, bacteria and fungi, e.g. Metarhizium anisopliae (Metch.) Sor. and Beauveria bassiana (Bals.-Criv.) Vuill. as well as nematodes (Samish et al., 2000), have the ability to reduce and weaken tick populations.

Research conducted by scientists shows that some plant species have deterrent properties and limit the occurrence of ticks in the area of cultivation of these plants, e.g. due to the intense smell caused by the release of specific essential oils into the air. However, it should be kept in mind that these are only experimental ways of fighting ticks so far. The research is carried out on selected species of ticks, on small populations, so this is not a fully proven method of protection against ticks. The plants listed 
by scientists in the literature include, among others: tansy (Tanacetum vulgare L. Appendix 1E) which is distinguished by a sharp spicy smell due to the essential oil - it repels not only ticks, but also mosquitoes, flies and aphids (Pålsson et al., 2008); horseradish (Armoracia rusticana P.Gaertn., B.Mey. et Scherb.) - an extract from the roots of horseradish not only repels but also kills ticks; catnip (Nepeta cataria L.) - contains nepetalactone - a compound that ticks and mosquitoes cannot tolerate (Birkett et al., 2011); sweet flag (Acorus calamus L.) - this plant's essential oil contains over $80 \%$ of azarone, which is a substance that repels ticks, mosquitoes, ants and flies (Ghosh et al., 2011); onion (Allium cepa L.) - according to Russian scientists, dried onion powder is one of the most effective ways to get rid of ticks (Aboelhadid et al., 2013); garlic (A. sativum L.) (Aboelhadid et al., 2013); wormwood (Artemisia absinthium L.) (Godara et al., 2015); wild garlic (A. ursinum L.); narrow-leaved lavender (Lavandula angustifolia Mill.) (Pirali-Kheirabadi, Teixeira da Silva, 2010); Tanacetum cinerariifolium (Trevir.) Sch. Bip. - the flowers of this plant contain cinerine and pyrethrin - toxic to insects (an extract from them is used in many insecticidal preparations); rosemary (Rosmarinus officinalis L. - Appendix 1F) (Martinez-Velazquez et al., 2011).

Repellents on sale are available in various forms: sprays, liquids in atomizers, lotions, gels, creams, wipes impregnated with a repellent substance, bracelets made of polyvinyl chloride (PVC) or silicone, plasters to stick on clothing or other surfaces, devices emitting ultrasonic sounds. In addition, pills, injections and spot-on are used for animals. Repellents may contain active substances of synthetic or natural origin. The most commonly used synthetic active ingredients are: N-N-diethyl-m-toluamide (DEET); ethyl ester of 3-(N-acetyl-N-butyl) amino propionic acid (IR3535); 1-piperidine-carboxylic acid KBR3023 (icaridine) (Przygodzka et al., 2019). In Poland, in 2016, research was carried out to determine the repellent effect of Dermacentor reticulatus Fabricius (meadow tick) ticks, products containing DEET, icaridine, IR3535 and a mixture of 3 substances: DEET, IR3535 and geraniol. Studies have confirmed that a repellent containing 30\% DEET showed 90\% repellence for ticks even after 7 hours from applying the repellent on human skin, while the activity of other substances decreased, the second best repelling compound was: 30\% DEET, 20\% IR3535 and 0.1\% geraniol (60\% of ticks not entering the skin after 7 hours). Products containing 20\% of icaridine and 12\% IR3535 repelled ticks effectively for 1.5 hour (Gliniewicz et al., 2019). However, it should be remembered that the tick species included in the research rarely attack humans, so it is necessary to carry out such experiments on a larger scale on the tick species I. ricinus most threatening the human species.

Ticks are very dangerous parasites for humans and animals, which in addition to causing direct effects of foraging (skin damage) can also be the transmitters of tickborne diseases. Currently, these parasites occupy many convenient habitats, have many hosts and the risk of an attack by ticks throughout Poland is a common phe- 
nomenon. Reducing the number of ticks will still remain the most sought after method for preventing these parasites from occurring in human and pet habitats, as well as from spreading dangerous tick-borne diseases. Research on controlling ticks is based mainly on chemical insecticides, which are not completely safe for humans and animals, and long-term tests of the environmental impact of these preparations are needed. There are several species of animals that eliminate the presence of ticks to some extent, and several species of plants that repel these dangerous parasites. However, the most promising method of bio-control so far is the use of fungal pathogens, reducing the number of ticks as well as affecting the movement and efficiency of parasites. All natural ways to prevent the occurrence of ticks are still sought after, improved and implemented in the environment, but it should be kept in mind that such actions do not cause changes in relationships in local trophic networks.

Acknowledgements

Thank you prof. Nowak-Chmura Magdalena for support and help in writing the article.

\section{Conflict of interest}

The authors declare no conflict of interest related to this article.

\section{References}

Aboelhadid, S.M., Kamel, A.A., Arafa, W.M., Shokier, K.A. (2013). Effect of Allium sativum and Allium cepa oils on different stages of Boophilus annulatus. Parasitology Research, 112(5), 1883-1890. DOI: 10.1007/s00436-013-3344-0

Angelo, I.C., Tunholi-Alves, V.M., Tunholi, V.M., Perinotto, W.M., Gôlo, P.S., Camargo, M.G., Quinelato, S., Pinheiro, J., Bittencourt, V.R. (2015). Physiological changes in Rhipicephalus microplus (Acari: Ixodidae) experimentally infected with entomopathogenic fungi. Parasitology Research, 114(1), 219225. DOI: $10.1007 /$ s00436-014-4181-5

Argas reflexus Fabricius: https://zeckenrollen.de/zecken/zeckenarten-in-deutschland/

Bezuidenhout, J.D., Stutterheim, C.J. (1980). A critical evaluation of the role played by the red-billed oxpecker Buphagus erythrorhynchus in the biological control of ticks. Onderstepoort Journal of Veterinary Research, 47(2), 51-75.

Birkett, M.A., Hassanali, A., Hoglund, S., Pettersson, J., Pickett, J.A. (2011). Repellent activity of catmint, Nepeta cataria, and iridoid nepetalactone isomers against Afro-tropical mosquitoes, ixodid ticks and red poultry mites. Phytochemistry, 72(1), 109-14. DOI: 10.1016/j.phytochem.2010.09.016.

Castellanos, A.A., Medeiros, M.C., Hamer, G.L., Morrow, M.E., Eubanks, M.D., Teel, P.D., Hamer, S.A., Light, J.E. (2016). Decreased small mammal and on-host tick abundance in association with invasive red imported fire ants (Solenopsis invicta). Biology Letters, 12(9), 20160463. DOI: 10.1098/ rsbl.2016.0463

Collatz, J., Selzer, P., Fuhrmann, A., Oehme, R.M., Mackenstedt, U., Kahl, O., Steidle, J.L.M. (2010). A hidden beneficial: biology of the tick-wasp Ixodiphagus hookeri in Germany. Journal of Applied Entomology, 135(5), 351-358. DOI: 10.1111/j.1439-0418.2010.01560.x

Duffy, D.C., Downer, R., Brinkley, C. (1992). The effectiveness of Helmeted Guineafowl in the control of the deer tick, the vector of Lyme disease. The Wilson Bulletin, 104, 342-345.

Ghosh, S., Sharma, A.K., Kumar, S., Tiwari, S.S., Rastogi, S., Srivastava, S., Singh, M., Kumar, R., Paul, S., Ray, D.D., Rawat, A.K. (2011). In vitro and in vivo efficacy of Acorus calamus extract against 
Rhipicephalus (Boophilus) microplus. Parasitology Research, 108(2), 361-370. DOI: 10.1007/s00436010-2070-0

Gliniewicz, A., Borecka, A., Przygodzka, M., Mikulak, E. (2019). Susceptibility of Dermacentor reticulatus ticks to repelents containing different active ingrediens. Przegląd epidemiologiczny, 73(1), 117-125. DOI: 10.32394/pe.73.13.

Godara, R., Parveen, S., Katoch, R., Yadav, A., Katoch, M., Khajuria, J.K., Kaur, D., Ganai, A., Verma, P.K., Khajuria, V., Singh, N.K. (2015). Acaricidal activity of ethanolic extract of Artemisia absinthium against Hyalomma anatolicum ticks. Experimental and Applied Acarology, 65(1), 141-148. DOI: 10.1007/s10493-014-9843-6

Ixodes ricinus L. female: https://www.gmx.net/magazine/wissen/natur-umwelt/zecken-nutzen-33586218

Ixodiphagus hookeri Howard: http://www.zeckenhilfe.com/en/all-about-ticks/article/what-are-the-natural-enemies-of-ticks-; Ixodiphagus hookeri attacking a fed female tick: https://alchetron.com/Ixodiphagus-hookeri

Martinez-Velazquez, M., Rosario-Cruz, R., Castillo-Herrera, G., Flores-Fernandez, J.M., Alvarez, A.H., Lugo-Cervantes, E. (2011). Acaricidal effect of essential oils from Lippia graveolens (Lamiales: Verbenaceae), Rosmarinus officinalis (Lamiales: Lamiaceae), and Allium sativum (Liliales: Liliaceae) against Rhipicephalus (Boophilus) microplus (Acari: Ixodidae). Journal of Medical Entomology, 48(4), 822-827. DOI: $10.1603 / \mathrm{me} 10140$

Pålsson, K., Jaenson, T.G., Baeckström, P., Borg-Karlson, A.K. (2008). Tick repellent substances in the essential oil of Tanacetum vulgare. Journal of Medical Entomology, 45(1), 88-93. DOI: 10.1603/0022-2585(2008)45[88:TRSITE]2.0.CO;2

Pirali-Kheirabadi, K., Teixeira da Silva, J.A. (2010). Lavandula angustifolia essential oil as a novel and promising natural candidate for tick (Rhipicephalus (Boophilus) annulatus) control. Experimental Parasitology, 126(2), 184-186. DOI: 10.1016/j.exppara.2010.04.012

Przygodzka, M., Mikulak, E., Chmielewski, T., Gliniewicz, A. (2019). Repellents as a major element in the context of prevention of tick-borne diseases. Przeglad epidemiologiczny, 73(2), 269-280. DOI: 10.32394/pe.73.25

Samish, M., Alekseev, E. (2001). Arthropods as predators of ticks (Ixodoidea). Journal of Medical Entomology, 38(1), 1-11.

Samish, M., Alekseev, E., Glazer, I. (2000). Biocontrol of ticks by entomopathogenic nematodes. Research update. Annals of the New York Academy of Sciences, 916, 589-594. DOI: 10.1111/j.1749-6632.2000. tb05341.x

Shaw, M.T., Keesing, F., McGrail, R., Ostfeld, R.S. (2003). Factors influencing the distribution of larval blacklegged ticks on rodent hosts. American Journal of Tropical Medicine and Hygiene, 68, 447-452. DOI: https://doi.org/10.4269/ajtmh.2003.68.447

Siuda, K. (1991). Kleszcze Polski (Acari: Ixodida). Część I. Zagadnienia ogólne. Warszawa, Wrocław: Wydawnictwo Naukowe PWN. [In Polish]

Tanacetum vulgare L.: http://www.nic.funet.fi/pub/sci/bio/life/plants/magnoliophyta/magnoliophytina /magnoliopsida/asteraceae/tanacetum/vulgare-2.jpg

The number of cases of selected tick-borne diseases in Poland. Data for day 30.09.2019: http://wwwold.pzh. gov.pl/oldpage/epimeld/index_p.html 


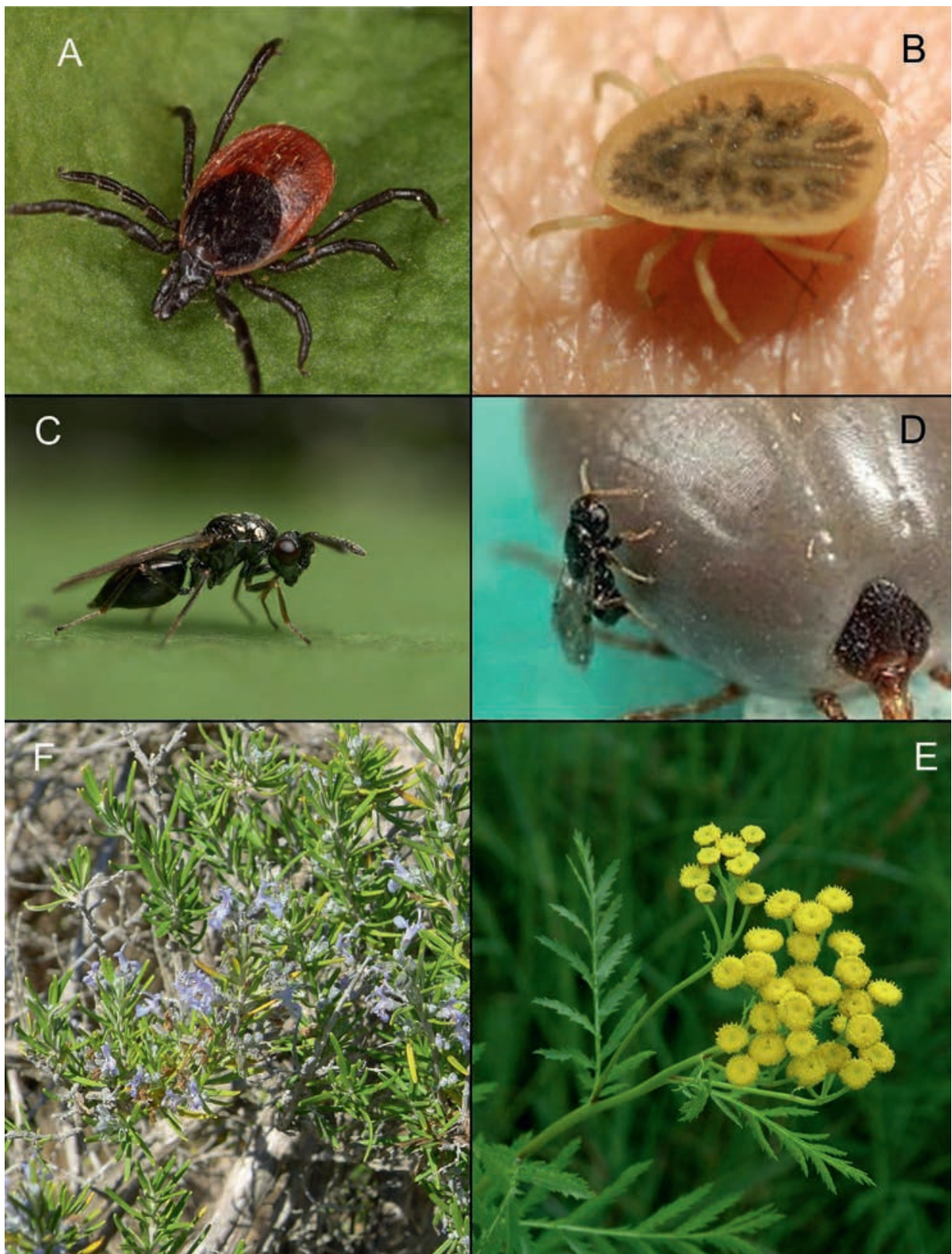

A - Ixodes ricinus L. female (Source: https:/www.gmx.net/magazine/wissen/natur-umwelt), B - Argas reflexus Fabricius (Source: https://zeckenrollen.de/zecken/zeckenarten-in-deutschland/), C - Ixodiphagus hookeri Howard (Source: http://www.zeckenhilfe.com/en/all-about-ticks/article/), D - Ixodiphagus hookeri attacking a fed female tick (Source: https://alchetron.com/Ixodiphagus-hookeri), E - Tanacetum vulgare L. (Source: http://www.nic.funet.fi/pub/sci/bio/life/plants), F - Rosmarinus officinalis L. (Photo. A. Kocoń) 
Kleszcze (Acari: Ixodida) należą do roztoczy, pasożytujących najczęściej na gadach, ptakach i ssakach. Ze względu na znaczenie epidemiologiczne, epizootiologiczne, jak również bezpośrednią szkodliwość wśród ludzi i zwierząt, zaliczają się do jednych z najgroźniejszych pasożytów zewnętrznych. Na całym świecie stwierdzono występowanie około 850 gatunków kleszczy, w Polsce, do tej pory stwierdzono 19 gatunków stale występujących w faunie naszego kraju. Bytują one w różnych siedliskach od terenów nizinnych aż po tereny górskie, zajmując takie miejsca jak: lasy, tereny zieleni, strychy budynków w tym mieszkalnych i gospodarskich, nory, jamy zwierząt, jaskinie. Coraz częstsze występowanie kleszczy w bliskim otoczeniu człowieka i zwierząt przydomowych oraz domowych stwarza idealne warunki do przenoszenia patogenów chorób odkleszczowych. Nie ma wątpliwości, że stale poszukiwane są wszelkie sposoby ochrony osobistej i działania środowiskowe, chroniące przed atakami kleszczy oraz przed konsekwencjami jakie mogą wystąpić po żerowaniu pasożyta.

Key words: parasite, tick protection, ticks

Received: [2019.08.08]

Accepted: [2019.11.15] 